\title{
Increasing student motivation and knowledge in mechanical engineering by using action cameras and video productions
}

\author{
McCaslin, S.E. ${ }^{a}$, Young, M. $^{\mathrm{b},{ }^{*}}$ \\ a Department of Mechanical Engineering, The University of Texas at Tyler, Texas, United States of America \\ bepartment of Management and Marketing, The University of Texas at Tyler, Texas, United States of America
}

\begin{abstract}
A B S T R A C T
Action cameras were used in a material science class laboratory setting for improving student motivation and understanding of material failure mechanisms. The design, implementation, and student perceptions were examined when using cameras. The students recorded video footage of destructive material testing using GoPro Hero action cameras in order to evaluate material failure and develop a video presentation. The use of action cameras allowed students to view and record their experiments without the risk of damage to a more expensive camera, view their experiments in slow motion, and improve technical communication skills. An assessment of the innovation was conducted through student feedback and existing performance measures related to continuous quality improvement. Students participated in developing a grading rubric for video laboratory presentations. Five criteria in order of importance were content, clarity, organization, format, and creativity. The students' surveys were positive regarding increased understanding of course material and improved technical communication skills. The students were satisfied with the variety of laboratory experiments. They perceived increases in their abilities to share technical information through a medium other than written reports. Implications included needing more training in camera usage, editing, and video production techniques in order to improve the learning process. This innovation could be extended to other engineering and management classes.
\end{abstract}

\section{ARTICLE INFO}

Keywords:

Mechanical engineering

Student learning

Materials management

Action camera

Video production

*Corresponding author: myoung@uttyler.edu (Young, M.)

Article history:

Received 17 June 2014

Revised 26 January 2015

Accepted 12 February 2015 


\title{
Povečanje motivacije in znanja študentov strojništva z uporabo akcijskih kamer in video produkcij
}

\author{
McCaslin, S.E. ${ }^{a}$, Young, M. $^{\mathrm{b},{ }^{*}}$ \\ a Department of Mechanical Engineering, The University of Texas at Tyler, Texas, United States of America \\ bepartment of Management and Marketing, The University of Texas at Tyler, Texas, United States of America
}

\begin{abstract}
POVZETEK
Da bi povečali motivacijo študentov in razumevanje mehanizma zloma materialov smo v laboratorijski učilnici za materiale uporabili akcijske kamere. Med uporabo kamer smo raziskovali študentovo zasnovo, implementacijo in dojemanje novih tehnik. Da bi ovrednotili zlom materiala so študenti posneli in pripravili video prikaz preizkušanja materiala s kamero GoPro Hero. Uporaba akcijskih kamer je študentom omogočila ogled opravljenih eksperimentov tudi v tehniki upočasnjenih posnetkov, prav tako pa je povečala preostale tehnične spretnosti. Ocena inovativnosti poučevanja je bila napravljena s pomočjo študentskega odziva. Z ozirom na pomembnost smo vpeljali pet meril, in sicer vsebina, jasnost, organizacija, oblika in kreativnost. Analiza je pokazala, da so se študenti pozitivno odzvali glede povečanja razumevanja snovi s področja materialov, prav tako pa tudi glede povečanja tehničnih spretnosti. Zadovoljni so bili s pestrostjo laboratorijskih eksperimentov. Zaznali so tudi povečanje sposobnosti delitve tehničnih informacij prek drugih medijev, ne samo prek pisnih poročil. Da bi izboljšali učni proces bi bilo treba več urjenj pri uporabi kamere, urejanja in tehnik video produkcije. Pričujoča inovacija bi se lahko uporabila tudi v preostalih razredih, kjer se poučujejo vsebine iz inženirstva in menedžmenta.
\end{abstract}

\section{PODATKI O ČLANKU}

Ključne besede:

Strojništvo

Učenje

Menedžment

Akcijske kamere

Video produkcija

*Kontaktna oseba: myoung@uttyler.edu

(Young, M.)

Zgodovina članka:

Prejet 17. junija 2014

Popravljen 26. januarja 2015

Sprejet 12. februarja 2015 


\section{References}

[1] Goodhew, P.J., Bullough, T.J. (2006). Active learning in materials science and engineering, Journal of Materials Education, Vol. 28, No. 3-6, 161-169.

[2] Davies, C.H.J., Hines, P.J., Ringer, S.P. (2001). A flexible learning studio for materials science and engineering, In: Towards Excellence in Engineering Education: Proceedings of the $12^{\text {th }}$ Australasian Conference on Engineering Education, $7^{\text {th }}$ Australasian Women in Engineering Forum, Brisbane, 245-250.

[3] Pinder-Grover, T., Green, K.R., Millunchick, J.M. (2011). The efficacy of screencasts to address the diverse academic needs of students in a large lecture course, Advances in Engineering Education, Vol. 2, No. 3, 1-28.

[4] Laoui, T., O'Donoghue, J. (2008). Development of a support environment for first year students taking materials science/engineering, Research in Science \& Technological Education, Vol. 26, No. 1, 93-110, doi: 10.1080/ $\underline{02635140701847553}$.

[5] Kurt, A.O., Kubat, C., Öztemel, E. (2006). Web-based virtual testing and learning in material science and engineering, International Journal of Engineering Education, Vol. 22, No. 5, 986-992.

[6] Mikulski, M.A., Szkodny, T. (2011). Remote control and monitoring of AX-12 robotic arm based on windows communication foundation, In: Czachórski, T., Kozielski, S., Stańczyk, U. (eds.), Man-Machine Interactions 2, Advances in Intelligent and Soft Computing, Vol. 103, 77-83, Springer, Berlin, doi: 10.1007/978-3-642-23169-8_9.

[7] Avery, A., Jacob, J. (2013). Evaluation of motion capture techniques in microgravity, In: 51st AIAA Aerospace Sciences Meeting including the New Horizons Forum and Aerospace Exposition, Dallas, Texas, USA, 10827-18240, doi: 10.2514/6.2013-731.

[8] Kindt, D. (2011). First impressions from recording in the classroom with a GoPro head-mounted camcorder, Academic Journal of the School of Contemporary International Studies, Vol. 11, 179-199.

[9] Tugrul, T.O. (2012). Student perceptions of an educational technology tool: Video recordings of project presentations, Procedia - Social and Behavioral Sciences, Vol. 64, 133-140, doi: 10.1016/i.sbspro.2012.11.016.

[10] Schultz, P.L., Quinn, A.S. (2013). Lights, camera, action! Learning about management with student-produced video assignments, Journal of Management Education, Vol. 38, No. 2, 234-258, doi: 10.1177/105256291348 $\underline{8371}$.

[11] Cochrane, T.A., O'Donoghue, M. (2008). Improving oral presentation skills of engineering students with the Virtual-i Presenter (ViP) program, In: Proceedings of the 2008 AaeE Conference, Yeppoon, Australia, 1-6.

[12] Armstrong, G.R., Tucker, J.M., Massad, V.J. (2009). Achieving learning goals with student-created podcasts, Decision Sciences Journal of Innovative Education, Vol. 7, No. 1, 149-154, doi: 10.1111/i.1540-4609.2008. 00209.x.

[13] Menekse, M., Stump, G.S., Krause, S., Chi, M.T.H. (2013). Differentiated overt learning activities for effective instruction in engineering classrooms, The Research Journal for Engineering Education, Vol. 102, No. 3, 346-374, doi: $10.1002 /$ iee.20021.

[14] CNET Editors, GoPro Hero2 Outdoor Edition, from http://reviews.cnet.com/digital-camcorders/gopro-hd-hero2outdoor/4505-6500_7-35055132.html, accessed August 14, 2013.

[15] McCaslin, S.E., Kesireddy, A., from YouTube Analytics: http://www.youtube.com/user/UTTylerMEProfMc, accessed February 15, 2013.

[16] Microsoft, Movie Maker - Microsoft Windows, from http://windows.microsoft.com/en-us/windows-live/moviemaker, accessed August 14, 2013.

[17] TechSmith, Camtasia Studio, from http://www.techsmith.com/camtasia-2gslp.html?gclid=CI3ApNKf_bgC FdGj4AodPU4AFg, accessed August 14, 2013. 